\title{
Women, Gender and Ecclesiastical History
}

\author{
by JANE SHAW
}

Outrageous women, outrageous god. Women in the first two generations of Christianity. By Ross Saunders. Pp. x+ I82. Alexandria, NSW: E.J. Dwyer, I996. \$Io (paper). o $85574278 \mathrm{X}$

Montanism. Gender, authority and the new prophecy. By Christine Trevett. Pp. xiv + 299 . Cambridge: Cambridge University Press, I996. E37.50. o 521 4 II82 3

God's Englishwomen. Seventeenth-century radical sectarian writing and feminist criticism. By Hilary Hinds. Pp. vii + 264. Manchester-New York: Manchester University Press, i996. £35 (cloth), £i4.99 (paper). o 7190 4886 9; о 7190 48877

Women and religion in medieval and Renaissance Italy. Edited by Daniel Bornstein and Roberto Rusconi, translated by Margery J. Schneider. (Women in Culture and Society.) Pp. $\mathrm{x}+334$ incl. I figs. Chicago-London: The University of Chicago Press, I996. (first publ. as Mistiche e devote nell'Italia tardomedievale, Liguori Editore, I992). £39.95 (\$50) (cloth), £i3.50 (\$I6.95) (paper). o 22606637 I; o 226066398

The virgin and the bride. Idealized womanhood in late antiquity. By Kate Cooper. Pp. xii + I80. Cambridge, Mass.-London: Harvard University Press, I996. £24.95. о 674939492

St Augustine on marriage and sexuality. Edited by Elizabeth A. Clark. (Selections from the Fathers of the Church, I.) Pp. xi+ri2. Washington, DC: The Catholic University of America Press, I996. £23.95 (cloth), £ir.50 (paper). o 8I32 o866 I; o 8I $320867 \mathrm{X}$

Gender, sex and subordination in England, I500-I80o. By Anthony Fletcher. Pp. xxii + $44^{2}+40$ plates. New Haven-London: Yale University Press, i995. \&25. o 300 o653I o

Empress and handmaid. On nature and gender in the cult of the Virgin Mary. By Sarah Jane Boss. Pp. $\mathrm{x}+253+9$ plates. London-New York: Cassell, 2000. £45 (cloth), £ig.99 (paper). o 30433926 I; o 304 7078I 3

'You have stept out of your place'. A history of women and religion in America. By Susan Hill Lindley. Pp. xi+50o. Louisville, Ky: Westminster/John Knox Press, I996. \$35. o 664 2208I 9 
7 he position of women within Christianity might well be described as paradoxical. The range of practices in the early Church with regard to 1 women, leadership and ministry indicates that this was the case from the beginning, and the legacy of conflicting biblical texts about the role of women - Galatians. iii. 28 versus I Corinthians xi. 3 and Ephesians v. 22-3 for example - has, perhaps, made that paradoxical position inevitable ever since. It might be argued, then, that the history of Christianity illustrates the working out of that paradox, as women have sought to rediscover or remain true to what they have seen as a strand of radically egalitarian origins for Christianity which has been subsumed by the dominant patriarchal structure and ideology of the Church. The tension of this paradox has been played out when women have struggled to act upon that thread of egalitarianism and yet remain within Churches that have been (and, it could be argued, remain) 'patriarchally' structured.

While scholars in ecclesiastical history and related fields have undoubtedly been influenced by the huge developments in both women's history and gender history in the larger arena of historical scholarship, they have also been influenced by the questions raised by feminist theologians about the viability of women remaining within the Churches and the outworking of Christian doctrine in the women's lives. 'Origins' have therefore become important to some feminist scholars, especially those of faith, in a rather distinctive way, as they have sought to bring to light - and, in some cases, discover - evidence for the ways in which the Christian tradition has in at least some of its roots an equal place for women. For example, Elisabeth Schussler-Fiorenza's work, In memory of her (1983), was a foundational text for feminist biblical and historical scholarship because it suggested a hermeneutic by means of which a scholar could gather, from the rather meagre amount of evidence in the New Testament about women, a sense of women's significance in the Jesus movement. ${ }^{1}$ Since that time, the growth of feminist biblical hermeneutics has been rapid and considerable, and much work has followed in its stead. This does not stop popular books being published in this area. Ross Saunders, in his book Outrageous women, outrageous god, does from time to time draw on scholarship of this sort but essentially he seeks to write a popular book about 'outrageous women' in the first two centuries of Christianity. 'Outrageous women' are, for him, those who 'stepped outside what was traditionally allowed them in their own society' (pp. ix-x). This book began as a series of lectures for some Anglican sisters in Saunders's Australia, and was written, he says, with the hope that

those of you who are men will realize the need to give back to women their rightful place in the kingdom of God, and that those of you who are women and feel the tug

1 Elisabeth Schussler Fiorenza, In memory of her: a feminist theological reconstruction of Christian origins, London 1983 . 
of the Holy Spirit in your innards will respond by offering yourselves wholeheartedly and optimistically for both lay and ordained ministry in Christ's church. (p. 2)

His theological justification for such a position is an 'outrageous God': 'That God would not only allow such behaviour but at times encourage it, means to some extent God is the origin of this outrageousness' (p. x). Saunders examines a series of New Testament passages about women, seeking to demonstrate the ways in which Jesus was radical. Ironically, his focus therefore becomes Jesus rather than the women he is discussing. A similar tactic leads to the reappropriation of Paul as one who 'stepped way beyond the mores of his time and continued the process of freeing women to be full members of society, a process begun by Jesus' (p. I53). This is clearly not a scholarly book; but even within the parameters of a popular treatment of the subject, Saunders relies on his own speculation far too much and tends towards the repetition of these speculations, rather than presenting, in a clear and accessible way, the scholarship of people working in the field. This weakness of the book is particularly apparent in the last chapter. His summary of the place of women in the post-apostolic Churches works on an older assumption that women were very quickly edged out of leadership roles - certainly by the end of the first century - and this is an assumption that Saunders needs to make in order to present Jesus and Paul in a radical light. More recent scholarship, such as that by Ute E. Eisen ${ }^{2}$ has used inscriptions and other non-textual evidence to illustrate the ways in which women continued in leadership roles - as bishops and deacons, for example - for many centuries. Local variations in gender roles must be taken into account, as with all things in early Christianity, and a more complex picture drawn. Saunders's schematic account is written in a lively and spirited way but if history is to be used for the theological and ecclesiological purposes which he sets out, then more nuanced and careful scholarship must form the foundation of such arguments.

The place of women - and, indeed, men - in the early Churches is an historical subject which is seen to have relevance to individuals and the Churches today: while Churches are still debating the validity of the ordination of women, and even the extent to which laywomen can participate in the worship and ministry of the Church, it is not possible to shy away from this. One of the great strengths of feminist scholarship has been to show that no scholar works from a neutral starting-point: the selection of topic and the evidence on which historians choose to focus are shaped by their presuppositions. Ecclesiastical historians, influenced by their experience of the Churches in their own day, have worked with certain assumptions about

${ }^{2}$ Ute E. Eisen (trans. Linda M. Maloney), Women officeholders in early Christianity: epigraphical and literary studies, Collegeville, MN 2000. 
the place of women in early Christianity, and this has led to historical inaccuracies. For example, it now seems likely that women and men were equally deacons in the first two centuries of Christianity in many places, and that a separate order of deaconesses with distinctive roles for women only fully emerged in the third century. Older scholarship wrongly assumed that women were deaconesses, rather than deacons, from the very beginning. Such a retelling of this story could have far-reaching repercussions for Churches which claim to base their ministerial structures in the Catholic tradition. It is not possible to pretend, therefore, that historical scholarship about women in Christianity (written from any number of perspectives 'feminist' or, in the language of recent years, 'traditionalist') does not have some bearing on questions of church polity and on some of the debates which rage fiercely today, but it is vital to recognise that feminist scholarship on these matters has reached a level of sophistication worthy of serious historical attention, frequently questioning the assumptions of older historians through painstaking examination of the sources, and thus setting into motion lively historiographical debates.

Christine Trevett's Montanism: gender, authority and the new prophecy is a model of balanced scholarship about a fraught topic. Montanism, a prophetical movement which emerged in the second century, has attracted attention from many quarters, associated as it has been with debates about church authority, women's ministry, millenarianism, the nature of sects, gifts of the Spirit, the nature of the biblical canon and much more. So, says Trevett, the 'study of Montanism has always been moulded by the concerns and the confessional stance of writers'. Two of the three prophets who were at the centre of the movement were women, and the movement as a whole encouraged women's ministry. This has meant that 'feminist reclaimers of the history of Christian women have seized on the Prophecy, sometimes with scant knowledge of its history and implications but conscious that here was a phenomenon in which (unusually in Christian history) women were prominent' (p. I2). Trevett sets out to write a book on the origins, development and decline of Montanism (hers is the first full-length study of the movement written in English since I878), in which she seeks to take particular account of women 'not just because of a need to redress an imbalance which exists in much church history writing (and such an imbalance is obvious to me) but because the sources for the history of Montanism are remarkable not least for the fact that women figure in them with much greater regularity than do men. This is not to be ignored' (p. I4).

Trevett's treatment of these sources is subtle and judicious. She rejects suggestions that the two female prophets, Priscilla and Maximilla, began the movement, but she does note that it was because they were greatly honoured leaders within their faith community that their oracles were written down, circulated and accorded high status - much to the chagrin of their enemies. Montanists were not the first group to enable women to exercise prophetic 
leadership: they did, however, insist on the primacy of prophetic leadership at a moment when certain groups within the Church were attempting to define 'orthodoxy', and when the three-fold order of ministry-bishop, priest and deacon - was beginning to emerge as the norm. The Montanists therefore caused consternation and alarm because they rooted authority in the Spirit and thus in the words their prophets uttered while 'in the Spirit'. Precisely because they allowed women and men to prophesy and exercise leadership on equal terms, this allowed the 'orthodox' and subsequent historians of the movement to demonise the role of women. Trevett quotes G. Salmon, in the nineteenth-century Dictionary of Christian biography, as typical of this attitude: 'If Montanus had triumphed, Christian doctrine would have been developed not under the superintendence of the Christian teachers most esteemed for wisdom, but of wild and excitable women.' Trevett argues, convincingly, that there was little, if anything, about the Montanists' beliefs for example, on the apocalypse, on fasting and purity, on martyrdom, on celibacy - that differed from the mainstream Church, but rather that it was their emphasis on the primacy of the Spirit and their equal treatment of male and female prophets that condemned them to the label of heterodox.

Throughout the history of Christianity, renewal movements have often attempted to practise what they have seen as a radical egalitarianism, rooted in the primitive Church, and they have consequently been especially appealing to women. Furthermore, such movements (or 'sects') have frequently claimed the Holy Spirit as their main 'teaching authority' and this has opened a space outside or on the margins of the institutional Church in which women have been able to assume prophetic leadership roles and thereby exercise public authority. The moments in the history of the Churches when this has occurred are often particularly rich in sources for women's religious history, and have come to be the focus of considerable scholarly attention in recent years. The mid-seventeenth century in England is one such moment, when the chaos of the civil war and Interregnum led to religious freedom and the development of numerous independent Churches - such as the Baptists, Quakers, Fifth Monarchists - claiming Scripture or the Holy Spirit as their only authority.

Keith Thomas pointed to the richness of this period for women's history in $195^{8}$ in a milestone article in Past and Present. ${ }^{3}$ Since then, historians and literary critics have drawn on the large quantity of prophetical writings, spiritual autobiographies and tracts written by women in this period, to produce a substantial body of work. Especially notable in this field is Phyllis Mack's Visionary women (1992), for it warned against imposing modern notions of agency onto a seventeenth-century sensibility and sought to understand these women prophets within the terms of their own culture, and most

${ }^{3}$ Keith Thomas, 'Women and the civil war sects', Past and Present xiii (1958), 42-62. 
especially in the religious terms in which they themselves operated - something which had sometimes been ignored by secular feminist and Marxist historians. She argued that women were not so much 'pursuing a covert strategy of self-assertion', rather, the ground of their authority as spiritual leaders 'was their achievement of complete self-transcendence, surely a very different subjective experience from that of the modern social activist or career woman'. 'Women were seen, in the seventeenth century, as more suited to the gift of prophecy because their 'natural' passivity enabled them to 'receive' the message of the Spirit more easily than men, while their 'irrational' and ecstatic behaviour, during periods of prophesying, made them the perfect symbols of 'the world turned upside down'.

Hilary Hinds draws on these insights in her literary treatment of seventeenth-century female prophets in God's Englishwomen: seventeenth-century radical sectarian writing and feminist criticism. Hinds analyses how seventeenthcentury religious women came to be writers, noting that 'typically this was not described as a decision or desire to write, but as a call or command to write, emanating from God and requiring obedient acceptance' (p. 87). For these women, the real author was God. They were - in a commonly used phrase merely 'worms'. Illness often produced the lowly circumstances - and the degree of faith necessary - in which these women became most receptive to God's word, as in the famous case of Anna Trapnel who prophesied publicly at Whitehall, from her bed. As Hinds says, 'God saves the author [from illness] in order that she might do his work' whilst 'the denigration of the self as a worm allows the emergence of a new self, one without human weakness and with new-found divinely ordained authority' (p. 97).

Hinds addresses these issues in relation to the debate within literary theory about the 'death of the author' triggered by Roland Barthes and Michel Foucault. This debate has evoked mixed responses from feminists - some positive for the inherent challenge to the existing literary canon, some negative for the ensuing erasure of the self when women, for example, have not been considered writing selves. ${ }^{5}$ While the use of literary theory is sometimes a little clunky in Hinds's work (this book reads at times like a doctoral thesis in which the author had to show the examiners she knew the theoretical debates), this book is of value to ecclesiastical historians, not least because Hinds asks questions about authority and authorship which are inherent to any discussion of the sources for theology and the role of revelation. She

${ }^{4}$ Phyllis Mack, Visionary women: ecstatic prophecy in seventeenth-century England, Berkeley-Los Angeles, $\mathrm{C}_{\mathrm{A}}$ 1992, 5 .

${ }^{5}$ For an example of that debate amongst feminist theorists see Seyla Benhabib, Judith Butler, Drucilla Cornell and Nancy Fraser, Feminist contentions: a philosophical exchange, New York-London 1995. For an historian's perspective on that debate see Carla Hesse, 'Kant, Foucault and three women', in Jan Goldstein (ed.), Foucault and the writing of history, Oxford I993, 8I-98. 
treats the religious context of these women writers with a proper seriousness, noting that religion was the foundational discourse on which politics and so much else was predicated.

Furthermore, Hinds suggests that it is necessary to treat texts from outside the canon - prophetical writings by Fifth Monarchist and Baptist women such as Mary Cary and Anne Wentworth, for example - as serious literary texts. In making her case, she is engaging with literary critics about the composition of the literary canon, but her argument could equally be addressed to theologians. What texts do Christian theologians allow into their canon? It is unlikely that university or theological college courses on the doctrine of revelation contain in their syllabuses texts by writers such as Mary Cary or Anne Wentworth or Anna Trapnel but perhaps they should, both for the acutely interesting questions such texts raise about the role of the prophet and the nature of ongoing revelation in Christian history, and for the ways in which they illustrate how, and how frequently, those on the margins of institutional religion - women, for example - speak in the voice of God or the gods, a point made long ago by anthropologists. ${ }^{6}$ All of this makes Hinds's book stimulating for ecclesiastical historians; and its appendices, containing extracts from writings by the prophets Mary Cary, Elinor Channel, Dorothy Waugh, Priscilla Cotton and Mary Cole, which are otherwise hard to obtain, are valuable for teachers of both ecclesiastical history and theology.

While women have been attracted to movements on the edge of institutional religion, for the freedom of expression and action they have found within them (however temporarily sometimes), they have, too, found ways to carve out a space for themselves at the heart of the Church. How have women exploited fissures in the institutional Church to give themselves a role and a voice? How and when have they exercised authority in the Churches, even with official consent, when they were not supposed to do so? How have women used the Christian notion of renunciation of worldly values in their spirituality to shape a role for themselves - that is, by exercising the 'power of the weak'? These questions are implicitly or explicitly at the heart of many of the ten articles in Women and religion in medieval and Renaissance Italy, edited by Daniel Bornstein and Robert Rusconi, written and published in Italian in the Ig8os and now elegantly translated into English by Margery J. Schneider. Much work has already been done to explore both the influence of medieval women in a society where the sacred and the secular were utterly intertwined, and the place of piety in the lives of medieval women. One of the most important scholars in this field is Caroline Walker Bynum, and her influence has been and remains far-reaching. Her work on the religious significance of food to medieval women, for example, asked broad questions

6 The classic text here is I. M. Lewis, Ecstatic religion: a study of shamanism and spirit possession, London i971, 2nd edn, London i989. 
about how and why women imitated Christ in their piety differently from men - and thereby made sense of some seemingly peculiar religious practices by women such as Catherine of Siena. ${ }^{7}$ Daniel Bornstein, in his introduction to Women and religion in medieval and Renaissance Italy, acknowledges the debt of scholars writing on women and religion in the Middle Ages to the work of Bynum (and other American scholars) while at the same time criticising her for forsaking 'careful distinctions of institutional identity' which have been 'progressively subsumed within the broader categories of gender'. His claim is that the strength of the Italian historians, whose work is translated in this book, is their focus on institutional history, 'alert to the play of power within institutions' and their 'intimate familiarity with rich local manuscript collections' (p. I2).

Undoubtedly, one of the values of this book is that it makes the scholarship of Italian medievalists, writing on north and central Italy, more widely available to English-speaking academics, while another is the precision and detail with which most of these Italian historians know and read their sources. However, Bornstein's dismissal of a more sophisticated analysis of gender in historical scholarship - and his implicit but false assumption that if you have that then you cannot have a pristine regard for the evidence - is reflected in the lack of analysis in some of the articles collected in this book. This is apparent, for example, in the first article, by Antonio Rigon, 'A community of female penitents in thirteenth-century Padua', which is based on very few archival documents and briefly describes the lives of three women who chose to become penitents. Rigon offers little in the way of explanation as to why these three women 'adopted the ascetical regime that the Church imposed on public sinners who had been absolved' (p. 3o). Nor does he indicate that he is any way 'alert to the play of power within institutions'. His observation that the female penitents had a relationship with San Luca, a chapel on its way to becoming a parish, results in the conclusion that "the religious experience of the three women evolved in the shadow of a church that was fully enmeshed in the ecclesiastical structures of the city' (p. 30). Platitudes of this sort do not pass muster as historical analysis.

A stronger piece by Enrico Menesto on Clare of Montefalco analyses the typology of sanctity at play in the documentation of the medieval proceedings (I318-I9) for her canonisation, which began ten years after her death. At her death, the sisters in her convent opened up her body and found in her heart the symbols of Christ's passion, and on her gall bladder three globes said to represent the Trinity. These were interpreted as miraculous signs, and thus

7 Caroline Walker Bynum, Holy fast and holy feast: the religious significance of food to medieval women, Berkeley-Los Angeles, $\mathrm{CA}_{\mathrm{A}} \mathrm{I} 9 \mathrm{8} 7$. See also her Fragmentation and Redemption: essays on gender and the human body in medieval religion, Cambridge, MA 1992. 
began the long process of research by the church authorities into Clare's life and virtues. Menesto provides a thorough and imaginative narrative of how a saint is made, indicating the various stages of the relationship between the cult of a person and canonisation. He roots Clare's sanctity in an experiential and 'affective' spirituality, stemming from a deep affinity with Christ's suffering, and in a 'serene and optimistic relation with the world and a complete dedication to other people' (p. I ig). But, strangely, Menesto makes no comment on the particular and peculiar sufferings of Clare - not least in her body - in her expression of sanctity, nor on the relationship between this charismatic woman and the institution of the Church, which stretched out her canonisation proceedings over 572 years. Here is a subject that cries out for the historian to use gender as a tool of historical analysis, but we are left without it, and thus we are left with our questions about power, the institutional Church and female sainthood, and about the distinctive expression of female sanctity in the fourteenth century, unanswered.

These weaknesses are, however, the exception rather than rule. Anna Benvenuti Papi's article on mendicant friars and female pinzochere in Tuscany is an exemplary piece of work for her analysis of the relative preponderance of women among the saints of thirteenth- and fourteenth-century Tuscany, and for the ways in which she charts the changing shape of female devotion, suggesting that informal female communities increasingly evolved into enclosed, more conventional monastic orders under the watchful eye of the mendicant friars. By examining the hagiographical material on these women, which was written and (more importantly, perhaps) revised by the mendicants, she is alert to the powerful role these men had in representing female sanctity. She also exercises the bread-and-butter skills of an excellent social historian, marking out the social and educational status of the different women whose lives she considers, and the differences between urban and rural expressions of piety. Chiara Frugoni's article, 'Female mystics, visions and iconography', reworks old material in a new light by pointing to the ways in which visual images were of particular value and use to lay women, especially lay female mystics. Gabriella Zarri provides a valuable typology of female sanctity in the early sixteenth century, illustrating the ways in which increasing emphasis was put on the virtues of a religious woman, and less on the gifts of prophecy and mysticism that had previously often given her a public voice.

It remained true in the Middle Ages that most (though not all) of the women who were able to exercise influence in the Church and who became saints were chaste - unmarried or widowed (for they generally had more room for manoeuvre than did women who were married with household responsibilities). This was of course the legacy of the early Church and late antiquity. The attraction of the ascetic life for women in that period has become a topic of much scholarly attention and debate in recent years. Kate Cooper's monograph, The virgin and the bride: idealized womanhood in late antiquity 
makes a distinctive and unusual contribution to that debate. Cooper opens the preface of her book with this question (p. ix):

why did the early Christians alight on the ideal of virginity, and why did the Romans come to adopt it as their own, even when they saw its triumph would undermine the very fabric of ancient society? It is a question that has troubled the historical profession since Gibbon, and no satisfactory answer has yet been found.

With the advent of women's history, this longstanding question had been reframed: why were so many (Christian) women attracted to the ideal of virginity, and to the renunciation it involved? Peter Brown, in his influential book, The body and society, provided an answer, suggesting that the elite women who became holy virgins - literally in the desert or in their cubiculum, the household symbol of the urban desert - were thus able to escape their limited place in the structure of the household, in which they were passed from father to husband, and the primary duty of child-bearing. ${ }^{8}$ They therefore experienced and exercised a certain kind of freedom and some even came to wield considerable power, as Susanna Elm illustrates in her Virgins of God: the making of asceticism in late antiquity. Elm's book is just one of a number of articles and monographs which have responded to, or built on, the conclusions of Brown's foundational work. ${ }^{9}$ This body of work generally focuses on the activities and perspectives of the Christians. Cooper shifts the focus again and addresses the question from the unusual perspective of the literate Roman in order to understand how they might have perceived the questions of sexual morality and religious allegiance at stake in this massive shift. She thereby places a series of Christian theological debates within the Roman culture in which they occurred, and asks from that vantage point why and how the Christian ascetic life came to be appealing to Roman women.

She does this first by tracing how the ancient novel - in which the desire of the hero and heroine was directed towards marriage and thus towards the continued stability and reinforcement of the social order - was re-cast in the early Christian 'romance tale' so that desire was redirected towards the divine and thereby became a challenge to the social order. In her examination of the apocryphal acts written between the second and fourth centuries, in which celibacy is often represented as the superior way of life, Cooper shows how the Apostle - Paul, in the Acts of Paul and Thecla, for example is a substitute for the romantic hero; upon hearing the Apostle's preaching

${ }^{8}$ Peter Brown, The body and society: men, women and sexual renunciation in early Christianity, New York ig88.

${ }^{9}$ See, for example, Elizabeth A. Clark, Ascetic piety and women's faith: essays on late ancient Christianity, Lewiston, NY i986; Virginia Burrus, Chastity as autonomy: women in the stories of the Apocryphal Acts, Lewiston, NY i987; Amy Ewing Hickey, Women of the Roman aristocracy as Christian monastics, Ann Arbor 1987; Gillian Cloke, The female man of God: women and spiritual power in the patristic age, $A D$ 350-450, New York 1995. This is by no means an exhaustive list of the recent literature on the history of asceticism in this period. 
the heroine desists from sexual relations with her husband (who is too stupid or stubborn to recognise the worth of the Apostle's message to the city), and she sets out on her quest for an otherworldly reunion with the Christian holy man. Cooper's reading of these texts is both textured and nuanced, and she shows that the challenge of the Apostle to the male householder is in fact nothing to do with women, but is a conflict between men, in which the Apostle - who, after all, represents the potential disruption to the social order - is nevertheless seen as clearly superior in moral and ethical terms. She argues that it is difficult to know much about the female readership of these texts in the second and third centuries - beyond speculation that they appealed to those already resentful of the imperial administration - but by the fourth century, elite women encountered these writings in unprecedented numbers, by which time, 'imitation of the heroine became the vehicle of identification for female audiences, and gestures of sexual renunciation took on an increasingly well-documented importance as a model for women of all classes' (p. 67).

The brilliance of Cooper's book is that she brings an older question, about the rise and influence of asceticism in Roman society, and a newer question, about why and how asceticism came to be appealing to Roman women, to bear on each other, thereby illustrating the level of analytical sophistication which is possible in historical scholarship when gender is taken into account in addressing the large questions which have driven our historiographical debates for decades or even centuries. The problem is that she does not fully answer either question - but perhaps it would be wrong to expect her to do so? At the end of the book, she cautions us against assuming that we know too much about women's religious experience in this period. She concludes (p. I43) - in answer to Peter Brown and others who have followed his line that we should be

warned against an easy acceptance of the early Christian literature of continence and rejection of family life as a literature of women's autonomy. To such an equation, the question must be put: which women? A second, more far-reaching question follows: what could autonomy itself mean to a population so deeply committed to the values of group and dynasty? These hard questions both deserve and demand further study.

By the end of the fourth century, there was a considerable body of writings on the merits of virginity and the ascetic life. It was in response to Jerome's more extreme writings in favour of asceticism that Augustine wrote one of the very few texts that was positive about marriage in this period, The good of marriage, in 4or. Elizabeth Clark provides edited selections from this and Augustine's other related writings in an excellent anthology entitled, St Augustine on marriage and sexuality. The enduring influence of Augustine's text on marriage on the western Church is indicated by Pope Pius XI's use of Augustine's three goods of marriage (offspring, fidelity and the sacramental bond) as the 
foundation of the significant I93o encyclical on marriage, Casti Conubii. The strength of Clark's edited collection is that she puts selections from this influential text alongside Augustine's other writings on sexuality, thereby showing that his views on these matters were more wide-ranging than a reading of only The good of marriage might suggest. For, as we know most famously from the Confessions, Augustine struggled with sexuality himself. He came to believe that even the sexual desire experienced by married couples was sinful to some degree, precisely because of original sin, and he subscribed to the prevalent belief that celibacy was, in the end, superior, and had been declared so by the Apostle Paul. Clark, by her judicious choice and arrangement of the selected texts, and in her short but valuable introduction, illustrates how Augustine always wrote on questions of marriage and sexuality in a particular (often pastoral) context, first against the Manicheans, then in response to the ascetic debates set in motion by writers such as Jerome in the 39os, and finally within his broader writings on original sin in response to the Pelagians. Clark has provided us with a useful selection of some very influential texts on the western Church's thinking about sexuality and, thereby, gender. This will be a helpful resource for teaching and for all those who are engaged in the ongoing debates about sexuality in most Churches today.

The influence of texts by figures such as Augustine on the construction of our notions of both gender and sexuality has been considerable, and points us to the question of the relationship between representation and 'reality': what were women (and men) told they could do and what did they actually do? How were notions of 'femininity' and 'masculinity' constructed differently across time and place and how did they affect who women and men thought they were and therefore what they could do? These are the foundational questions of much recent work on gender history as it developed out of women's history in the ig8os and I99os. Thus far, this review article has been primarily about the history of women and Christianity, and the books discussed have largely attempted to narrate and analyse women's religious, spiritual and intellectual activities within the institutions - and sometimes on the fringes - of Christianity. This historical enterprise is in part about 'filling in the gaps' of the existing picture though such stories, when told, necessarily shift and change that existing overall picture, just as the discovery or use of any new archive would. But there is of course a strong relationship between what a person feels or thinks they can do as a woman or as a man - that is within the prevailing ideologies of the time - and what they actually do, whether within the parameters of, or in defiance of, those ideologies. Anthony Fletcher's Gender, sex and subordination in England, I500-I800 attempts to address this relationship and to take into serious account both women and men as 'culturally constructed' beings.

Fletcher's intention is to look at how patriarchy adapted and survived between 1500 and I80o in England, and to that end he uses a wide range of 
historical and literary sources: conduct books, medical texts, drama, ballads and proverbs, letters and diaries. In this enterprise he is, in part, following the well-trod path of Lawrence Stone and those who followed him; but their lens was the family, and their methodology social history. ${ }^{\mathbf{1 0}}$ Fletcher brings to his scholarship the insights of gender history, literary history, feminist theory, the history of sexuality and the history of medicine, all of which have been significantly developed since Stone and others engaged in their debates. To explain the development of patriarchy, Fletcher draws from and builds on the influential work of Thomas Laqueur, who argued, in Making sex, that from the early modern to the modern period, people went from thinking about women and men as 'one-sex' (as established by Galen) to thinking about them as two sexes. To put it another way, this period saw a shift from gender hierarchy - in which women were thought of as inferior versions of men - to sexual difference, in which they were considered distinctly different from men. ${ }^{11}$ Fletcher applies the arguments of Laqueur's intellectual and medical history 'on the ground', to see how this development was played out in popular literature in the English context. This is a successful and fascinating feature of the book, complementing well Laqueur's argument and evidence.

In the early modern period, then, gender fluidity was always a danger: if there was only 'one sex' then women could become dangerously 'masculine' or men threateningly 'effeminate.' The ideology of patriarchy, argues Fletcher, was about ensuring that women and men behaved within the proper, prescribed ways, and he produces plenty of evidence to support this thesis. He also builds on the work of scholars such as Susan Amussen to show that this brought about something of a crisis in the ordering of society, as evidenced by the endless production of conduct literature about how women could best be governed (and controlled). ${ }^{12}$ If the household were kept in proper order then, it was believed, society would be kept in proper order, for the household was 'a little commonwealth'. Fletcher negotiates very nicely the relationship between a prescriptive text such as William Gouge's wellknown and oft-cited Of domesticall duties (I622) and the lived reality of household relations through his use of diaries and correspondence.

The shift to the two-sex model, argued Laqueur, occurred in the eighteenth century, not generally because of new scientific discoveries (though the shift was often expressed in the emerging language of science) but through ideology. As a new discourse on rights developed, the pressing question of who had rights emerged: if women were not to be given rights in the new political order (and very few people seriously thought they should be) then some justification had to be given. The answer resided in the new idea of

10 Lawrence Stone, The family, sex and marriage in England, I500-I80o, New York 1977.

11 Thomas Laqueur, Making sex: body and gender from the Greeks to Freud, Cambridge, Ma I990.

12 Susan D. Amussen, An ordered society: gender and class in early modern England, Oxford I988. 
sexual difference - two sexes - in which women and men were thought to be different from each other. Drawing on Laqueur's work and that of other historians such as Ludmilla Jordanova and Londa Scheibinger, ${ }^{13}$ Fletcher suggests that in the English context, after I66o, the male gentry emerged as the secure leaders of society and were the impulse behind this new and more stable ideology of patriarchy; in tandem with new developments in philosophy, religion and science, stability was produced in the form of the polarisation of the sexes, and the relegation of women to the domestic sphere. The last third of Fletcher's book is concerned with illustrating this thesis and he explores the new constructions of masculinity and femininity through a range of primary sources. His chapter on women and religion in this section is, however, somewhat disappointing. His sources are, primarily, published funeral sermons for godly women, and women's own spiritual autobiographies and accounts of their private devotions. While this gives some evidence of the day-to-day devotions and religious attitudes of educated women, and how men saw them, this provides a limited view. Fletcher, surprisingly, does not turn to the female prophets of the civil war, despite the number of primary sources and the wealth of secondary scholarship, nor, for example, to the plentiful evidence (mostly in the John Rylands Library) of Methodist women preachers in the eighteenth century. Thus he misses the opportunity to see how women both fashioned and challenged their place in the Churches - institutions which epitomised and underpinned the values of the patriarchal society which Fletcher attempts to analyse.

Fletcher's book suffers from the weakness of omissions in several areas and at times it fails to draw out the complexities of the patriarchal system, the lived tensions between prescription and practice, symbol and reality. The book's strength is that it is a piece of interesting gender history with a clear line of argument and interdisciplinary underpinnings; furthermore, it sums up much that has developed in the field and is thus a valuable teaching resource, as well as being a starting point for future discussions in much the same way that Stone's book on the family - for all its flaws - was for an earlier generation.

Sarah Jane Boss in her book on the changing meaning of the Virgin Mary in western culture, Empress and handmaid: on nature and gender in the cult of the Virgin Mary, turns our attention to the power and influence of symbols, a topic sadly missing from Fletcher's analysis. Boss argues that images of the Virgin Mary shifted from the Middle Ages - when she was depicted as a figure of authority and usually as a mother enthroned with child - to the modern era when she is generally represented as a figure standing alone, young and domesticated without the regal authority of previous eras. One only has to think

13 Ludmilla Jordanova, Sexual visions: images of gender in science and medicine between the eighteenth and twentieth centuries, Hemel Hempstead I989; Londa Scheibinger, The mind has no sex?, Cambridge, MA I989. 
here of the Romanesque statues and sculptures of the Virgin Mother in the cathedrals of medieval France - truly a God-bearer as the Eastern Orthodox tradition would put it - and contrast them with the statue of the rather insipid young virgin at the grotto at Lourdes, and its many reproductions around the world. Cultural and social historians like Laqueur and Fletcher might explain that by speaking of the association of women - now constructed as a distinctly different species from man - with the domestic in the modern era, and draw on a wide range of sources to illustrate the shift. Boss, however, turns not to the historical specificities which might explain why, in certain places and times, the symbols of the Virgin Mary shifted - the historian's usual method - but to the sweeping theories of Adorno, Horkheimer and the Frankfurt School on the theme of domination. Boss argues that in the earlier period the power resided in the symbol, drawing the viewer in; by contrast, in the modern period, shaped as we are by a pornographic culture, we dominate the image, mastering it. She argues, 'the placing of a huge emphasis upon Mary's personal submission and selflessness is a fairly recent development, which, like pornography, is characteristic of modernity' (p. I2). This modern attitude, she argues, is typical of the mechanical age in which we live, and illustrates our increasing domination and fear of both nature and women in modernity. While this book makes for a stimulating and provocative read, this argument may make historians uncomfortable for its generalisations about modernity and its implicit and ahistorical association of women and/or motherhood with 'nature'. Boss's observations about the changing nature of the symbol of the Virgin Mary are interesting, but her explanation as to why this shift occurs is deeply problematic for an historian, relying as it does on overarching theoretical explanations which cannot allow us to take into account the specificities of a particular historical context, nor the ways in which a symbol is viewed and interpreted differently by different people and communities. The book's value to an historian, then, is that it raises questions which require more historically accurate answers, and it should therefore act as a stimulus to further research on the changing nature of Christian symbols over time, their influence and varying interpretations in different cultures, and their power in affecting how we think of ourselves as women and men in any given time or place.

This article has assessed, through a review of a range of books published in the second half of the last decade, the state of scholarship in the field formed by the intersection of women's history, gender history and ecclesiastical history. While, in many ways, this is still a 'young' field, we have reached a point in some areas where works of synthesis can be written. Fletcher's book was one such work, though not, of course, directly in the area of ecclesiastical history. A valuable work of synthesis directly in the field of women's religious history is Susan Hill Lindley's 'You have stept out of your place' : a history of women and religion in America. Drawing on the rich and varied scholarship of the past three decades in this area, Lindley does not attempt to offer new evidence 
or even a provocative new interpretation, but rather a narrative survey of women's participation in American religious life, from Anne Hutchinson in seventeenth-century Massachusetts to the feminist theologians working at the end of the twentieth century. This survey covers the activities and beliefs of women in the mainline Christian denominations, Judaism, native American religions and the various heterodox and utopian religious groups which developed in the eighteenth and nineteenth centuries - the Shakers, Oneida Perfectionists, Mormons, Christian Scientists and Spiritualists - which rethought many of the prevailing assumptions about gender both in their theology and in their community life. At the end of the book she examines the multi-faith context of the contemporary United States and looks at the participation of women in Hinduism, Islam and Buddhism. In her chapters on the nineteenth century, she rightly relates women's religious activity to their activism in movements for the abolition of slavery and for the vote, and her chapter on African-American women's participation in church life illustrates well the relationship between Church and politics for that community.

This is an excellent survey text for the teaching of American religious history, bringing together in one volume the large amount of research which has been done in this field. The next step would, of course, be to produce a textbook on American religious history which brings together women's and men's religious activities and thought. Indeed this is a key development for the field of ecclesiastical history - just as it is for all history; that is, to produce scholarship which systematically examines the relevant issues of gender 'in its stride' and is alert to what the evidence tells us about the representation and activities of women and men - separately and in relationship to each other in all religious arenas. Lindley's book points us, too, to a further development in ecclesiastical history: that is, away from any trace of its old confessional stance and towards a dispassionate analysis of all religious expression and activity. Because women's religious participation has often been on the fringes of the institutional Church and their writing in non-canonical texts, historians of women have had to go beyond the usual archival territory of church history. As historical scholarship on gender and religion develops, it might, then, be a model for future work as we reshape the field of ecclesiastical history in a multi-cultural and multi-faith society. 